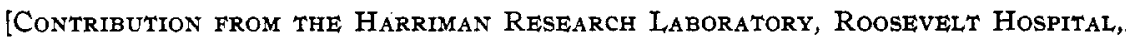
NEW YORK.]

\title{
STUDIES ON ENZYME ACTION. XIII. THE LIPASE OF SOY BEANS. \\ By $\mathbf{K}$. Georget FalK. \\ Received January $7,1915$.
}

In continuation of the study of lipolytic activities reported in previous papers, ${ }^{1}$ the results obtained in the study of the lipase of soy beans by methods similar to those used in the study of castor bean and duodenal lipases will be given.

Two preparations were used in this work: S.B. I; yellow soy beans, ground, extracted with ether in a Soxhlet apparatus, dried in air, and ground to pass through a 40-mesh sifter; S.B. II; the shells of the soy beans were removed by hand, the kernels ground, extracted with ether, air dried, and ground to pass through a 40-mesh-sifter.

To test the activities of the preparations, the weighed substance with the stated amount of water or of solution in a stoppered Erlenmeyer flask was placed in the incubator at $38-40^{\circ}$ with the ester (either I cc. ethyl butyrate, denoted by $\mathrm{EtBu}$, or $0.5 \mathrm{cc}$. glyceryl triacetate, denoted by Triac.) for 24 hours, and then titrated with approximately 0.I $N$ standard $\mathrm{NaOH}$ solution, with phenolphthalein as indicator. The final results, corrected for blanks, alone are given, and represent the number of cc. of $0.1 \mathrm{~N}$ acid formed under the conditions stated by the action of the lipase upon the ester. Toluene was used throughout as antiseptic.

The effect of heating and of drying on the activity of S.B. II was studied and the results are given in Table I. The first column indicates the treatment before testing; the second, the amount of substance used; the third, the loss in weight in grams; the fourth, the percentage loss; and the fifth and sixth the activities of $0.18 \mathrm{~g}$. portions of the treated material in $25 \mathrm{cc}$. water, except for the first row where the activities of $0.2 \mathrm{~g}$. portions of untreated material are given.

Table I.-Activity of Soy Bean Lipase Preparation after Drying and Heating.

\begin{tabular}{|c|c|}
\hline \multirow{2}{*}{ Treatment. } & \\
\hline & $\begin{array}{l}\text { S.B. II. } \\
\text { Grams. }\end{array}$ \\
\hline
\end{tabular}

None.

Treatment.

Grams. Grams.

Et Bu. Triac.

\begin{tabular}{|c|c|c|c|c|c|}
\hline & & & & & \\
\hline $100-110^{\circ}, 3 \mathrm{hrs} \ldots \ldots \ldots \ldots \ldots \ldots$ & I.0399 & 0.0894 & 8.60 & 0.20 & I. 54 \\
\hline $\mathrm{CaCl}_{2}$ desiccator, 3 days $\ldots \ldots \ldots \ldots$ & I .0097 & 0.0685 & 6.78 & 0.36 & $2 \cdot 78$ \\
\hline $\mathrm{CaCl}_{2}$ desiccator, 2 days.......... & 1.0080 & 0.0587 & 5.82 & $\ldots$ & . \\
\hline $\mathrm{CaCl}_{2}$ desiccator, 2 days more $\ldots \ldots \ldots$ & $\ldots$ & 0.0635 & 6.30 & . & . \\
\hline then IOO-I I0, 3 hrs... & & 0.0874 & 8.67 & O. I I & I. 37 \\
\hline $\mathrm{P}_{2} \mathrm{O}_{6}$ desiccator, 2 days............ & I. .0089 & 0.0864 & 8.56 & $\ldots$ & $\ldots$ \\
\hline $\mathrm{P}_{2} \mathrm{O}_{5}$ desiccator, I day more......... & $\ldots$ & 0.0871 & 8.63 & 0.34 & 2.67 \\
\hline $\mathrm{P}_{2} \mathrm{O}_{5}$ desiccator, 3 days $\ldots \ldots \ldots \ldots$ & 1.0070 & 0.0931 & 9.24 & $\cdots$ & $\cdots$ \\
\hline then $100-110^{\circ}, 3 \mathrm{hrs} . \ldots \ldots \ldots \ldots$ & . . & 0.0941 & $9 \cdot 34$ & 0.17 & I. 49 \\
\hline
\end{tabular}


The loss in weight due to drying did not decrease the activity, but an almost equal loss in weight due to heat decreased the activity $50 \%$. Similar results were obtained with castor beans except that with them almost the whole of the activity was lost in heating.

Series of experiments were made in which the activity of both soy bean preparations was tested in solutions containing salts and alcohols of different concentrations. In each test $25 \mathrm{cc}$. of solution and $0.2 \mathrm{~g}$. of preparation were used. The action on ethyl butyrate in water alone is small, so that practically no effect was noticeable due to added substance in most cases. Only in o.r $N$ sodium fluoride and in the most concentrated sodium chloride solutions were marked retardations observed. Table II shows the results obtained with triacetin in salt solutions of the indicated concentrations.

Table II.-Activity of Soy Bean lipase Preparation toward Triacetin in VARIOUS SOLUTIONS.

\begin{tabular}{|c|c|c|c|c|c|}
\hline & S.B. Y. & S.B. II. & & S.B. I. & S.B. II \\
\hline $\mathrm{H}_{2} \mathrm{O}$ & 2.70 & 2.87 & $0.01 M \mathrm{MgSO}_{4}$ & 3.22 & \\
\hline $0.01 M \mathrm{NaCl}$ & 2.98 & $\ldots$ & 0.02 & 3.17 & $\ldots$ \\
\hline 0.02 & 3.08 & $\ldots$ & 0.05 & $3 . \mathrm{II}$ & 3.17 \\
\hline 0.05 & 3.28 & $3 \cdot 44$ & o.I & 2.65 & $\ldots$ \\
\hline 0.1 & 3.31 & $3 \cdot 52$ & $0.002 M \mathrm{MnSO}_{4}$ & $3 \cdot 13$ & $3 \cdot 4^{6}$ \\
\hline 0.2 & 2.90 & 3.20 & $0.05 M \mathrm{CH}_{3} \mathrm{OH}$ & 2.76 & 2.61 \\
\hline 0.5 & 2.44 & $\ldots$ & 0.1 & $\ldots$ & 2.53 \\
\hline I.O & 1. 79 & 2.53 & 0.2 & 2.54 & 2.78 \\
\hline $0.05 M \mathrm{NaBr}$ & $3 \cdot 37$ & $\ldots$ & 0.5 & 2.65 & 2.40 \\
\hline O. I & 3.46 & 3.60 & 1.0 & 2.29 & $\ldots$ \\
\hline 0.2 & $3 . I I$ & 3.38 & o. oI $M \mathrm{C}_{2} \mathrm{H}_{5} \mathrm{OH}$ & $\ldots$ & 2.74 \\
\hline 0.5 & 1.95 & $\ldots$ & 0.02 & $\ldots$ & 2.52 \\
\hline o. I $M \mathrm{NaI}$ & 2.46 & $3 \cdot 16$ & 0.05 & 2.53 & 2.49 \\
\hline o. I $M \mathrm{NaF}$ & 0.40 & 0.34 & $0 . \mathrm{I}$ & 2.51 & 2.57 \\
\hline o.I $M \mathrm{Na}_{2} \mathrm{SO}_{4}$ & $\ldots$ & 2.23 & 0.2 & 2.54 & 2.52 \\
\hline 0.2 & $\therefore$ & x.95 & 0.5 & 2.26 & $2.3 \mathrm{I}$ \\
\hline 0.5 & $\ldots$ & I. 39 & I.0. & 1.90 & \\
\hline
\end{tabular}

The S.B. II preparation showed a greater activity than did the S.B. I preparation in almost every case. With sodium chloride, the activity increased with increase in concentration of the salt until the concentration o.r $N$ was reached, and then decreased with more salt. . With sodium bromide, a similar maximum activity was observed at o.I $N$. Sodium fluoride exerted a very marked retardation. Magnesium sulfate accelerated in dilute ( $0.01 M$ to $0.05 M$ ), and retarded in more concentrated solution. Manganous sulfate accelerated strongly. Methyl alcohol and ethyl alcohol exerted no appreciable effect in dilute solutions (up to about $0.1-0.2 M$ ); at greater concentrations, retardation was observed. This was greater with ethyl alcohol than with methyl alcohol. On the whole, these lipase actions towards triacetin in solutions of different substances resemble very closely those previously reported with the 
castor bean and duodenal lipases, so that similarities in their chemical nature may fairly be deduced from the similarities in their chemical behavior under various conditions.

Some extraction experiments were made with S.B. I. ${ }^{1} 0.2$ g. of preparation was treated with $25 \mathrm{cc}$. water for the lengths of time indicated, filtered through asbestos with suction, the activities of the filtrates tested and the residues either extracted again or tested for lipolytic action. The results are given in Table III.

Table III.-Action of Aqueous Extractions of Soy Bean Preparation (S.B. I) on (a) Eithyt Butyrate and (b) Triacetin (24-Hour Tests).

$$
\text { Filtrate. Residue }\left(\mathrm{H}_{2} \mathrm{O}\right){ }^{2} \text { Total. }
$$

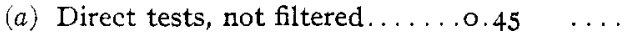

One minute extraction.............. 0.13

24 hrs. extraction................. 0.17

Second successive 24 hrs. extraction..., 0.02

$\begin{array}{ll}\ldots . . & \ldots . \\ 0.31 & 0.44 \\ 0.15 & 0.32 \\ 0.17 & 0.36 \\ \ldots . & \because \ldots \\ 1.29 & 2.36 \\ 0.93 & 2.38 \\ 0.87 & 2.56\end{array}$

(b) Direct tests, not filtered......2.70

One minute extraction.............. I.07

24 hrs. extraction................. I.45

Second successive 24 hrs. extraction...... 0.24

0.87

$2 \cdot 56$

The fractional parts of the two types of activity extracted by water did not differ much. This, taken with the preceding results, indicates that very little, if any, esterase (active toward ethyl butyrate) is present in the soy beans, but that considerable quantities of lipase (active toward triacetin) are. The amounts of the latter which were extracted by water ranged from $45 \%$ for the one minute extractions to $66 \%$ for two successive $24 \mathrm{hrs}$. extractions. These results differ markedly from the results obtained with castor bean preparations, which showed two types of action which could be separated by their different solubilities.

The filtrates obtained in these extractions were somewhat cloudy as a rule. On dialyzing these for $24 \mathrm{hrs}$. in collodion bags against running water, the cloudiness was increased with the separation of small amounts of precipitate. These dialyzed solutions on repeated filtration through hardened filters gave perfectly clear solutions which showed very nearly the same activity toward triacetin as the original undialyzed extracts. The solubility of the lipase of soy beans to form a clear solution in water is in marked contrast to the properties of the castor bean enzymes. There the esterase was found to be soluble and the lipase insoluble in water. The addition of three volumes acetone to the soy bean lipase solution precipitated a light gray powder, which, after grinding with fresh acetone and drying in a vacuum desiccator showed no activity, and on analysis gave a nitrogen content (Kjeldahl) of $14.0 \%$.

${ }^{1}$ Cf. IX Paper, This Journal, 35, I904 (1913), for similar experiments with the castor bean lipase preparation.

${ }^{2}$ Residue treated with $25 \mathrm{ce}$. water and the activity tested. 
A number of extraction experiments were made with sodium chloride solutions of different concentrations. In these, 0.5 g. S.B. II were extracted with $60 \mathrm{cc}$. solution for $24 \mathrm{hrs}$. at room temperature, filtered through asbestos, the filtrates dialyzed for $20 \mathrm{hrs}$. in collodion bags against running water, and then tested for 24 hrs. The results were corrected for purposes of comparison to show the activities obtained from $25 \mathrm{cc}$. of original undialyzed extract. Toward ethyl butyrate practically no activity was shown by the extracts. Toward triacetin the following mean results were obtained:

Conc. $\mathrm{NaCl}$ solution..... o $\quad 0.5 M_{1} .0 M_{1.5} M_{2.0} M_{2.5} M_{3.0} M$ Saturated

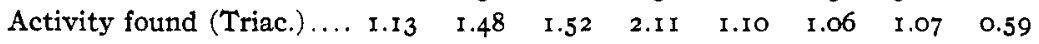

A marked maximum is observable for the $\mathrm{I} .5 M$ solution; that is to say, this solution extracted most active lipase, almost twice as much as water. The behavior of these salt solutions toward soy beans is strikingly similar to their behavior toward castor beans. ${ }^{1}$ In both cases, the maximum quantity of lipase is extracted by I.5 $M$ sodium chloride solution (about $9 \%$ solution). This concentration of salt solution is also very near that generally used in extracting proteins from seeds. ${ }^{2}$ The residues from extracting the soy beans with the different salt solutions on a second extraction and filtration with salt solutions of the same strength as before, showed very little activity in the filtrates.

Some analyses of the S.B. II preparation may be of interest. The methods used were the same as those previously described. The substance, dried in a vacuum desiccator over phosphorus pentoxide, showed a nitrogen content of $8.9 \%$, ash $4.46 \%$, $\mathrm{P}_{2} \mathrm{O}_{5} \mathrm{I} .4 \mathrm{I} \%, \mathrm{CaO} 0.3 \mathrm{I} \%$, and $\mathrm{MgO} 0.66 \%$. The forms of combination of the nitrogen in the preparation, according to Van Slyke's method, were the following, expressed as percentages of the total nitrogen: Ammonia, 10.6; melanine, 4.3; arginine, I6.0; cystine, 3.7 ; histidine, 5.7 ; lysine, 6.5 ; amino nitrogen in filtrate, 47.I; non-amino nitrogen in filtrate, 3.3 ; total, $97.2 \%$. The preparation gave strong tests for tyrosine. (Folin reagent) and for carbohydrates (Molisch test).

The writer wishes to thank Mr. K. Sugiura for his aid, especially in making the analyses, and Mr. M. Erenstoft for his help in much of the experimental work.

\section{Summary.}

The lipolytic properties of soy beans were studied by the methods used in the similar studies of castor beans and of duodenal contents.

$\dot{A}$ comparison of some of the properties of these hydrolytic enzymes showed the following relations:

Soy beans contain a lipase active toward triacetin (and therefore presumably toward fats), somewhat soluble in water, with a maximum solubility in I.5 $N$ sodium chloride solution. Castor beans contain an esterase soluble in water and a lipase insoluble in water and soluble in sodium

${ }^{1}$ XII Paper of this series, ThIs Journal, 37, 217 (I9I5).

2 Cf. Osborne, "The Vegetable Proteins," I909, p. 16. 
chloride solution with a maximum solubility at the concentration $\mathrm{r} .5 \mathrm{~N}$. Duodenal contents contain an esterase and a lipase, the former predominating in the intestinal juice, the latter in the pancreatic juice and bile.

Marked similarities in the action of neutral salts and alcohols are shown by the lipases from different sources.

The action of heat and of drying on the soy bean lipase was found to be similar to their action on castor bean lipase and esterase.

The analyses of the soy bean lipase preparations showed no marked differences in comparison with the analyses of the castor bean preparations.

NEW YORE, N. Y.

[CONTRIBUTION FROM THE BIOCHEMICAL LABORATORY OF THE UNIVERSITY OF ILLINOIS.]

\section{ENZYMES OF THE CENTRAL NERVOUS SYSTEM.}

BY H. M. ENGLish AND C. G. MacARThUR.

Received January 13, 1915.

The enzymes of the brain and nerves have not been investigated as thoroughly as those of most other tissues. This is rather surprising when one considers the supreme importance of the nervous system. Most of the previous data on brain enzymes has been obtained as part of other investigations, the enzymes of the nervous system having been considered only incidentally. The work here presented had for its object the beginning of a more systematic study of the enzymes of nervous tissue and a somewhat more detailed study of the most important ones.

\section{Preparation of Extracts.}

For the larger part of this work fresh sheep brains, packed in ice soon after removal from the animals and expressed directly from Chicago, were used. The membranes and blood vessels were removed and the brain divided into cerebrum, cerebellum, medulla, mid-brain, and, in some cases, corpus callosum. These divisions were minced separately in a meat grinder, then ground to a fine state in a mortar, with either toluol or oil of mustard as a preservative, usually the latter, and extracted with water $0.2 \% \mathrm{HCl}, 0.9 \% \mathrm{NaCl}, 0.5 \% \mathrm{Na}_{2} \mathrm{CO}_{3}$, chloroform water or glycerin. In each case $\mathrm{I} \mathrm{cc}$. of the liquid was used for each gram of brain tissue.

As a check on this method and also for the sake of comparison with other methods the following procedures were carried out:

The ground tissue (with or without preservative) was spread in thin layers on watch glasses and placed in large desiccators. The glasses were surrounded by a cylindrical screen outside of which calcium chloride was placed. The desiccator was placed in a jar and packed with ice and salt. When the tissue was frozen the desiccator was evacuated. By frequent renewing of the vacuum the tissue could be dried in one to two days. A part of this dried material was tested directly while the rest was ex- 